\title{
Social Stigma in Adolescents Who Do Early Marriage at School Age
}

\author{
Diah Rahayu ${ }^{*}$, Stefanny Ayu Danny², Novi Rizky Ramadhani ${ }^{3}$, Alda Niarisma ${ }^{4}$
}

1,2 Psychology Study Program, Mulawarman University, Samarinda, Indonesia

\section{A R T I C L E I N F O}

\section{Article history:}

Received September 19, 2021

Revised September 20, 2021

Accepted October 23, 2021

Available online November 25, 2021

Keywords:

Social Stigma, Adolescents,

Early Marriage

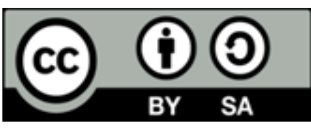

This is an open access article under the CC BY-SA license.

Copyright (C) 2021 by Author. Published by Universitas Pendidikan Ganesha.

\begin{abstract}
A B S T R A C T
Based on the results of a survey about teenage pregnancy of 7 adolescents aged 13-15 who were pregnant before marriage, who were still educated SLTP when pregnancy occurred. Early marriage is the most phenomenal symptom that often invites negative social stigma for society. Based on that, early marriage is an arranged marriage or marriage involving two parties between a man and a woman under the age of 18 years, which will usually give rise to negative stigma from the surrounding environment. Purpose of this study is to know people's views on early marriage and to know the level of social stigma against early marriage. Research method used in this research is qualitative research method, the approach used in this research is phenomenology. The study was conducted in Samarinda and several interviews were conducted in direct interaction with four subjects who had had early marriages in their teens or schools. The sampling technique used in this study is purposive sampling. The study subjects numbered 4 people. The results show factors that led to the subject of B.C. marrying young were due to parental and cultural factors. The factor that causes MAF subjects to have early marriage is the presence of pregnancy factors outside of marriage. RS gets a negative response from the surrounding environment and the factors that cause social stigma in subject RS. are the presence of knowledge and education. The reason AR married young are due to the parental factor.
\end{abstract}

\section{INTRODUCTION}

During the human life span, there is a lot of growth and development from birth to death. Of all these phases of human development, one of the most important and most important centers of attention is adolescence. Parents, educators, and other professionals try to explain and take an effective approach to dealing with these teenagers (Ahyani et al., 2018; Ali, 2016). Adolescence is also referred to as a period of change, the rate of change in attitudes and behavior during adolescence parallels physical changes (Fadhila, 2017; Mubasyaroh, 2016). Adolescence is a period of transition between childhood and adulthood, where there is growth, secondary sex traits arise, fertility and psychological and cognitive changes occur. The psychological dangers experienced by adolescents during puberty are: 1) Poor self-concept, 2) Low performance, 3) Lack of preparation to deal with changes in puberty, 4) Deviations in sexual maturation. There are several age restrictions in this period, namely the middle childhood period that begins when the child is 6 years old to the child is 9 years old. Then the end period of childhood (late childhood) is the age range of 9-12 years. At this time given the basis of further education because the child belongs to the age of school. School age is when a 6-year-old starts elementary school until the age of 17 where the child usually completes his or her schooling (Ali, 2016; Hati et al., 2013). But in the modern era as it is today there are still school-age children doing early marriage. Early marriage can generally be defined as a matchmaking relationship or marriage involving two parties between a man and a woman under the age of 18 years (BKKBN, 2012). Based on data from the Central Statistics Agency (BPS), the prevalence of child marriage shows a very concerning figure, where 1 in 4 or 23 percent of girls in Indonesia married as children. Every year about 340,000 girls marry under the age of 18 .

In 2017, the percentage of child marriage has reached 25.17 percent (Dhewy, 2019). Based on data from the Central Statistics Agency (BPS), as many as 94.72 percent of early married children experience school dropouts. 94.72 percent of women aged 20-24 years have been married under the age of 18 years and do not attend school again. While those who continued school only ranged from 5.28 percent (Dhewy, 2019). Based on Indonesian law regulated in Law No. 1 of 1974 states that marriage is only allowed if the

*Corresponding author.

E-mail: diah.rahayu@fisip.unmul.ac.id 
man reaches the age of 19 (nineteen) years and the woman has reached the age of 16 (sixteen) years. The change in norms in Law No. 1 of 1974 on Marriage reaches the age limit for marriage and the improvement of norms reaches by raising the minimum age of marriage for women. In Law No. 16 of 2019 the minimum age of marriage for women is equal to the minimum age of marriage for men, which is 19 (nineteen) years. The age limit is considered to have matured his physical soul to be able to hold a marriage to realize the purpose of marriage well without ending in divorce and getting healthy and quality offspring. Several studies both in Indonesia and the world show varied factors that encourage early marriage. The ICRW and UNICEF studies in Africa and South Asia found geography, religion, culture, and education to be the main factors behind the occurrence of early marriage (ICRW, 2005; Nasrin, 2012; UNICEF, 2005). For the Indonesian context refers to the results of early marriage held by Plan Indonesia and PPKUGM concluded that there are several dominant factors that drive the high number of early marriages, namely sexual behavior and unwanted pregnancy, traditions / cultures, low knowledge of sexuality or reproductive health, low education of parents, as well as socio-economic conditions, regional and geographical characteristics, and weak legal enforcement (Ariefuddin, 2016). Furthermore, the results of studies in Africa, South Asia, the Middle East, and Indonesia explained that early marriage affects more female children than boys. Therefore, early marriage is more of a reflection of gender misalignment and injustice and is considered to have violated THEHAM (UNICEF, 2005).

The factors that affect early marriage are culture, education, parents, and pregnancy out of wedlock (Jamilah \& Raudlatun, 2019). The above is in accordance with the results of interviews with MAF subjects via WhatsApp video call on May 4,2021, at 14:35 WITA, that the factors that encourage MAF to marry young due to having to be responsible because of the extramarital pregnancy factor caused by MAF. Furthermore, the results of the interview by the RS in Jalan Girimukti, Penajam on May 18, 2021, at 10:20 PM, that the reason for the young married subject was also due to the factor of getting pregnant out of wedlock. Based on the results of a survey in Sengon Agung Village about teenage pregnancy of 7 adolescents aged 13-15 who were pregnant before marriage, who were still educated in SLTP when pregnancy occurred. Early marriage is the most phenomenal symptom that often invites negative social stigma for society. Social stigma is a society's attitude towards a different group or perceived as abnormal (Varamitha et al., 2016). While, the factors that influence social stigma are the presence of knowledge, perception, education level, and age (Fiorillo et al., 2016).

Based on an interview with the subject of SM at the subject's Shop, Jl. Gn. Merbabu, Samarinda on May 1, 2021, at 16.00 WITA stated that the subject received a negative response from his relatives in the form of the subject's inability to educate children due to subjects who did not continue their education. While the results of an interview by the RS in Jalan Girimukti, Penajam on May 18, 2021, at 10:20 PM wita stated that when deciding to marry young, the subject's neighbors had suspected that the reason the subject married was due to the factor of getting pregnant out of wedlock. It is not yet clear the dominant factor that drives the high of early marriage is what drives this research to be important and strategic to be done so that it is found that the dominant factor will be formulated a strategic policy model to stop the practice of early marriage. Referring to the background of the high number of early marriages, the main problem of this study is what are the dominant factors that encourage / contribute to the high number of early marriages. In general, the study aims to identify and analyze the dominant socio-cultural factors contributing to the high rate of early marriage. People's views are fundamentally diverse over the reality of early marriage. Still high rates of early marriage in society show that this social reality is considered commonplace. However, not a few people tend to avoid or reject the practice of marriage with various considerations such as the child still wants to continue school, considered immature, and the child does not want to marry. To explain early marriage as a social action it would be wise to put the practice of early marriage into a micro perspective as described by Parson (voluntarism idea) and Weber (action theory) where the individual is a free, active, and creative actor in subjective decision-making of his social action (Alimandan, 1985; Hagedorn. R, 1990).

Basically, early marriage is more an accumulation of the impact of various complex socio-cultural factors, including the results of the process of socializing values in society. This means that in the perspective of Weber's interpretation, the behavior of early marriage must be placed on understanding and social behavior of society (Hagedorn. R, 1990). Furthermore, according to the interpretive perspective that social behavior reflects one's mind gained from his or her life knowledge and experience (Poloma, 2000). Therefore, a person's socio-cultural background becomes important in interpreting early marriage. Exploring and reviewing the meaning of early marriage from various social statuses and socio-cultural backgrounds of the community is a strategic step to identify various factors as an effort to formulate a comprehensive model of early marriage prevention that does not blame each other between individuals and groups but is instead more a comprehensive and wise solution. 


\section{METHODS}

The research method used in this research is a qualitative research method. The approach used in this study is phenomenology. The study was conducted in Samarinda and several interviews were conducted in direct interaction with the four subjects who had had early marriage in their teens or school age. The sampling technique used in this study is purposive sampling (sample aimed). In this study researchers used as many as four subjects detailed in Table 1.

Table 1. Demographic Overview of Research Subjects

\begin{tabular}{ccccc}
\hline Information & SM & MAF & RS & AR \\
\hline Age & 17 years & 22 years & 21 years & 20 years \\
The Last Education & SMP & SD & SMP & SMP \\
Year of marriage & 2017 & 2013 & 2014 & 2015 \\
Reasons to Marry & Love and fear & Pregnant out of & Pregnant out of & Fear of \\
Young & zina & wedlock & wedlock & adultery \\
\hline
\end{tabular}

Data collection methods in this study was an observation and interview. Observation is a data collection technique for observing human behavior, work processes, and natural symptoms, and respondents (Sugiyono, 2016). The purpose of the observation method is to observe the behavior of the subject verbally and nonverbally and find out whether the interview results match what is observed through this method. Interview is a way of collecting data used to obtain information directly from the source (Subana \& Sudrajat, 2009). An interview is a subjective report of a person's attitude toward the environment and toward himself. In carrying out this study, researchers conducted data analysis techniques with Miles and Huberman models. Activities in qualitative analysis are carried out interactively and continue continuously until complete, so that the data is saturated (Miles et al., 2014). Activities in data analysis, namely: (1) Data Reduction: The data obtained from the field is quite a lot, for that it needs to be recorded carefully and in detail. Reducing data means summarizing, choosing the main things, focusing on the things that are important. Then look for themes and patterns. The data is reduced by testing its validity and its relevance to the research topic and the theoretical foundation used; (2) Data Presentation: Once the data is reduced, the next step is to present the data. In the presentation of data can be done in the form of brief descriptions, charts, relationships between categories, flowcharts, and the like. The most used way to present data in qualitative research is with text that is narrative; (3) Conclusion or Verification: The results of research that have been collected and summarized must be repeated by matching the data reduction and presentation of data, so that the conclusions that have been studied can be agreed to be written as a report that has the correct level of trust. Qualitative research makes researchers the main instrument of data collection. In contrast to quantitative research that examines the validity of instruments, qualitative research examines the validity of the data (Putra \& Lestari, 2013). The validity of data in qualitative research requires criteria and examination techniques (Sugiyono, 2016). The criteria and techniques for checking the validity of the data can be seen in Table 2 .

Table 2. Criteria and Techniques for Checking Data Validity

\begin{tabular}{ll}
\hline Criterion & Inspection Techniques \\
\hline Credibility (Degree of Trust) & 1. Extension of observation. \\
& 2. Increased persistence of observation. \\
& 3. Triangulation. \\
& 4. Peer checking. \\
& 5. Member checking. \\
& 6. Negative case analysis. \\
7. Referential adequacy. \\
Sidetracked & Detailed description. \\
Dependency & Dependency audit. \\
Certainty & Audit of certainty. \\
\hline
\end{tabular}

\section{RESULTS AND DISCUSSIONS}

\section{Results}

Researchers have conducted interviews on all four subjects namely SM, MAF, RS, and AR. The interview stage is conducted at a predetermined time with the subject. The interview is conducted by giving 
a question to the subject, then the subject answers the question smoothly without obstacles according to what is experienced. As for the description of each subject's statement regarding the picture of the results of the study as follows.

\section{Attitude}

SM subject in the attitude aspect showed the results of interviews that showed that SM subjects insisted on wanting to get married at a young age in addition to avoiding adultery SM also love each other with the husband, because he understood the situation of marrying young SM and the husband promised not to want to have children first and focused on building a future by taking care of the store. In terms of attitude, the subject of the MAF and the family tried to take responsibility by marrying the MAF subject early with the wife, the MAF family came to the wife's family, and they ended up planning the wedding of the MAF subject, while MAF's male friends and cousins responded to the MAF's young marriage jokingly. In the aspect of attitude showing the subject of the RS initially did not dare to tell the family that the subject had been pregnant but because the RS subject was confused to do what at a young age finally the subject ventured to talk to the family, anger is the response given by the subject's family next the subject's family came to the boy's family to hold him accountable. In the aspect of attitude, according to AR marriage is worship and perfecting religion, AR parents also suggest that AR get married so that when AR wants to ask permission to marry both parents there are no obstacles. Initially AR had hesitated to get married, but after AR thought about it the subject also set his goal to marry as undergoing worship.

\section{Subjective norms}

In the aspect of subjective norms, people around SM such as parents, close relatives, and friends show pro (supportive) and cons (reject) attitudes. In the aspect of subjective norms, the MAF subject does not feel regret when married young because according to the subject, he is spared from association using illegal drugs. In subjective norms, the subject of the RS shows feelings of sadness at only seeing his friends spend youth in a different way from the subject, but the subject tries to remain passionate and sincere in living his current life. In the aspect of subjective norms, AR does not feel regret when doing early marriage, the subject only feels sad because playing time with friends is not what it used to be because AR friends who have their own busy lives.

\section{Perceived Behavioral Control}

In terms of perceived behavioral control, SM experienced obstacles in the form of not being able to manage the marriage record because it was too young and oblique comments from close relatives. In terms of perceived behavioral control, MAF subjects found more differences of opinion with their parents when preparing for marriage. In the aspect of perceived behavioral control, the RS gets obstacles in preparing for the wedding such as not knowing what to do and then scolded by parents, and there are differences of opinion between families in preparing for the wedding. In the aspect of perceived behavioral control, AR had felt confused and stressed when preparing for a wedding, but AR did not prepare everything alone, AR is assisted by parents and more experienced people.

\section{Cognition}

SM subjects in the aspect of cognition showed interview results that showed that SM subjects believed his decision to marry young did not get negative comments from neighbors or friends of the subject only close relatives who questioned the decision of the subject. In the process of cognition, the RS sometimes becomes the subject of oblique comments from neighbors and distant relatives of the RS, sometimes there are neighbors who ask the RS why the subject is very quickly married, in addition to the RS friends also start to keep their distance even away from the RS because the subject did an early marriage, although the RS feels sad because it was shunned by his friends, the subject has been able to accept it. In terms of cognition, AR families took issue with AR education, the family argued that men should be highly educated to get a decent job, while people in the subject environment had suspected that AR had children out of wedlock.

\section{Disinfection}

In the aspect of affection, SM showed feelings of sadness because of the words of his close relatives who argued that SM would not be able to be a good mother to her children because SM married at a young age and had not completed her education. In the process of affection, the subject of the MAF sometimes finds himself talked about by people around his home but the subject of the MAF chooses silence and does not consider it. In the aspect of the affection process, the subject feels that those closest to him give oblique comments that drop R.S.'s self-esteem such as not being able to take care of the household properly, the subject will quickly divorce, and something that makes the subject of R.S feel ashamed. R.S. subjects can only 
respond with silence and sometimes cry when recalling the words of those who made the oblique comments.

\section{Conation}

In the conation aspect, SM shows a tendency to not listen too much to the opinions of those around him and not to take too much issue with the opinions of those around him. In the conation process aspect, R.S can only accept oblique comments from neighbors and relatives, and when shunned by his friends the RS can only accept it.

\section{Parents}

In the parental factor, the subject of SM tried to convince his parents that his decision to marry young would be fine, because the parents of SM subject married at the age of 19-20 while SM was still sitting in junior high school already wanting to get married so that made the parents of SM subject feel worried. In the parental factor, the results of the subject interview showed that the parents were. R.S felt worried because the subject married at a young age, the parents felt the lack of preparation from R.S to start a household. R. S also has a feeling of fear of not being accepted in the neighborhood and having no friends after R.S got married later. In the parental factor, AR argues that his parents only suggest and there is no compulsion factor for AR to marry young immediately after getting advice from his parents, AR feels ready and will try to take responsibility in married life, because knowing the impact of young marriage for a teenager, AR and wife delay to have children.

\section{Culture}

In cultural factors, the closest relatives of SM subjects do not agree with SM marriages that are considered too young or early so that sometimes SM subjects still receive oblique comments from relatives, while the environment where SM lives many also do early marriages so that SM's actions are considered reasonable.

\section{Perception}

In terms of perception, the subject of the MAF found people sometimes argued that someone whose school was not high, would not get a good job, but according to the subject of MAF, he got a pretty good job.

\section{Knowledge}

In the knowledge factor, subject R.S argues that the people in his office have a view if there is someone who marries young let alone a woman, then the person will be suspected of getting pregnant out of wedlock, but when married out of his own will be viewed as a good thing.

\section{Education}

In the education factor, SM subjects get negative comments from people around who come from high school education backgrounds and sometimes get advice from higher education levels such as teachers. In the education factor, MAF subjects get negative comments from people who according to the subject of education are not high, MAF also sometimes get advice from teachers and close family who have a bachelor's degree. In the educational factor, subject R.S got a negative comment that dropped where R. S only to elementary school from people who are in higher education In the educational factor, AR subjects found comments from people around who had diverse education, if someone who had a higher education, according to the SUBJECT AR they would throw more relaxed words. In the knowledge factor, according to AR his environment just accepts the subject of early marriage, the first time AR spread the invitation of many people in the AR environment gave oblique comments about prospective AR wives pregnant out of wedlock, but after knowing the truth people in the AR environment look ordinary.

\section{Pregnant Out of Wedlock}

In the factor of pregnancy outside of marriage, the subject of MAF when first becoming a father MAF feels happy because it learns how to care for a baby, but had crossed the feeling of regret when having children because they had to take turns taking care of children at night with the wife and when the morning MAF had to work, then MAF got advice from his parents who made MAF able to live it until now. In the young pregnant factor, R.S experienced confusion in caring for the child, although R. S has a sister subject feels caring for a sister with a child of her own has a difference. In caring for the child, the RS gets help from the subject's mother. 
Age

In the age factor, according to the subject SM the relatives of the subject who often made oblique comments towards SM aged about 30 years, while for friends who were the same age as the subject SM behaved casually towards the subject's early marriage. In the age factor, when the MAF subject gets negative comments, The subject does not care much about it, in contrast to the subject's wife who sometimes feels hurt because of comments from people around him. In the age factor, subject R.S often gets slanted comments from his 40-year-old neighbors in addition to friends who are the same age as subject R. S also stay away from the subject because they have the view that the subject is R.S has a bad influence on them. In the age factor, AR subjects often get a negative view of people around the subject who are 30 years old, while for friends who are the same age as AR subjects view AR marriage as something natural or natural.

\section{Discussion}

This study discusses the social stigma in adolescents who do early marriage at school age. Early marriage occurs because of the theory of plan behavior characterized by attitudes, subjective norms, and perceived behavioral control (Huda, 2015). This early marriage creates a social stigma that is the things that bring disgrace to society, shameful things, and something where someone becomes humble, ashamed, and afraid of something (Hati et al., 2013).

\section{Causes of Early Marriage}

The factors that cause the subject to marry young due to the parental factor, the subject tries to convince his parents that his decision to marry young will be fine and the subject's parents are married at the age of 19-20. According to research, because of the low level of education and welfare levels make the mindset of parents become resigned and accepting, so the nature of surrender is what makes parents less understanding of the regulations on Marriage Law No.1 of 1974 (Jamilah \& Raudlatun, 2019). In addition to parental factors that cause subjects to do early marriage, researchers found the existence of cultural factors, namely the environment of the subject also conducted early marriage (Jamilah \& Raudlatun, 2019). The third cause of early marriage is betrothed (Mubasyaroh, 2016). On the other hand, the occurrence of early marriage is caused by the influence or even coercion of parents. Where there are several reasons, parents marry off their children because they are worried that their children are plunged into promiscuity and have negative consequences. Therefore, parents match their children with their relationships or children's relationships, namely with the reason that the property owned does not fall to others but is still held by the family.

This is supported by the results of research obtained results that factors related to early marriage are factors of the role of parents in family communication, parental education and education of respondents and the most dominant factor of early marriage in the study is the role of parents in family communication (Desiyanti, 2015). The decision of the subject in conducting early marriage not only gets a positive response but also gets a negative response from people around and this gives rise to a growing social stigma in the community. Researchers found that subjects fulfilled aspects of cognition that is subjects believed their decision to marry young did not get negative comments from neighbors or friends of the subject only close relatives who questioned the subject's decision. Furthermore, the factors that cause the subject to do early marriage are the factor of getting pregnant out of wedlock, the subject when first becoming a father feels happy because he learned how to care for the baby, but had crossed the feeling of regret when having children because they had to take turns taking care of children at night with the wife and when the morning had to work, then get advice from his parents who make MAF can live it until now.

This is supported by the research of Promiscuity encourages the occurrence of early marriage (Ahmad, 2011). So that the family or parents of women do not feel ashamed if their child is pregnant without a husband and family or male parents are not to blame because their children have impregnated people's children then early marriage is carried out. This causes many problems, especially in rural communities, whose children eventually quit school, are still young burdened with complex problems, and negative community views of those who carry out early marriages. The second cause of early marriage is pregnancy out of wedlock. The occurrence of pregnancy out of wedlock because teenagers have relationships that violate religious norms, forcing them to conduct early marriage to clarify the child conceived. In addition, with the occurrence of marriage in marriage, parents encourage their children to marry at young ages (Mubasyaroh, 2016).

\section{Social Stigma in Early Marriage}

Social stigma obtained, namely educational factors, knowledge, and age factors, get negative comments from people around. The level of education can affect the emergence of stigma, if the level of higher education then the level of knowledge will also be high (Fiorillo et al., 2016). The results of this study are in 
accordance with opinion in the hamlet of Pereng Ampel, Pamoroh Village, Madura district with the title of preventing early marriage to form a quality generation that is obtained by the driving factors of early marriage are economic factors, self-factors, educational factors, and parental factors (Sa'diyah, E, 2013).

In the age factor, subjects often get a negative view from people around the subject who are 30 years old, while for friends who are the same age as the subject, they view marriage as something unnatural or unnatural. The older a person gets, the more one's attitude and behavior changes so that one's thinking can change. The results of this study are in accordance with previous research in Banjarmasin district south of Banjarmasin city with the title of perception of high school students towards early marriage in Banjarmasin district south of Banjarmasin city which obtained the results that students at State High School 9 Banjarmasin, State High School 10 Banjarmasin, State High School 13 Banjarmasin stated that they did not agree with the existence of early marriage because it was due to the interest of students who Still want to continue education to a higher level and not ready emotions owned by teenagers to conduct marriages that will later result in divorce and domestic violence and will also occur risky pregnancies that occur by young women (Agustariana, F. et al., 2015).

Furthermore, when doing early marriage get social stigma seen in the social stigma that is the process of affection that sometimes finds itself talked about by people around his house. The process of affection is the provision of an individual's emotional evaluation of the hatred given to him or her (Utami, 2018). An attitude, the more positive a person's view of a behavior, the higher the desire to marry early (Huda, 2015). In the aspect of the attitude of marriage is worship and perfect religion, parents also suggest agar married so that ethics want to ask permission to marry both parents there are no obstacles. Based on the above statements it can be known that early marriages performed by teenagers who are still at school age cause various responses or social stigma in society. In the subject of SM and ar subjects who are married because of the desire and positive view of marriage can prevent a person from committing adultery so that it becomes a strong reason why the subject of SM and AR perform marriage at school age, but the positive outlook and desire to marry get the pros and cons of relatives, family, and the surrounding environment. The social stigma that arises in the subject of SM and AR subjects in the form of inability to take care of the household to be lived and the view that someone who married young and stopped to continue education could not get a decent job. Different from the subject of the RS and the subject of MAF who married due to the factor of pregnancy outside of marriage and trying to account for his actions due to promiscuity carried out makes the subject of RS and MAF get a negative social stigma in the form of losing closest friends, getting oblique comments that drop the subject's self-esteem such as not being able to take care of the household properly, the subject will quickly divorce, and something that causes shame. The weaknesses in the study were the lack of long-term observations (directly) to find out the level of social stigma in subjects who had early marriage at school age, as well as the lack of interviews conducted by researchers.

\section{CONCLUSION}

In this section the researcher presents and explains conclusions based on the results of research and discussions made by the researchers. The conclusion of this study is that the factors that cause young marriage are due to parental and cultural factors. Pregnancy factors outside of marriage and social stigma that arises as a result of early marriage are educational factors, knowledge and age factors, getting negative comments from people around.

\section{REFERENCES}

Agustariana, F., Angriani, P., \& Hastuti, K. P. (2015). Persepsi Pelajar Sekolah Menengah Atas Terhadap Pernikahan Usia Dini Di Kecamatan Banjarmasin Selatan Kota Banjarmasin. Jurnal Pendidikan Geografi, 2(4). https://doi.org/10.20527/jpg.v2i4.1430.

Ahmad, Z. (2011). Dampak Sosial Pernikahan Dini. Universitas Islam Negeri Syarif Hidayatullah.

Ahyani, L. N., Pramono, R. B., \& Astuti, D. (2018). Empati dan efikasi diri guru terkait kegiatan belajar mengajar bebas bullying. Intuisi: Jurnal Psikologi Ilmiah, 10(2), 141-151. https://journal.unnes.ac.id/nju/index.php/INTUISI/article/view/17489.

Ali, M. (2016). Psikologi Remaja Perkembangan Peserta Didik. Bumi Aksara.

Alimandan. (1985). Sosiologi Masyarakat Sedang Berkembang. CV. Rajawali.

Ariefuddin, A. (2016). Problem Perkawinan Anak di Indonesia. Qureta.

BKKBN. (2012). Buku Pedoman Pelaksanaan Jaga Mutu Pelayanan Keluarga Berencana. BKKBN.

Desiyanti, I. W. (2015). Faktor-Faktor yang Berhubungan Terhadap Pernikahan Dini Pada Pasangan Usia Subur di Kecamatan Mapanget Kota Manado. Jikmu, 5(2). https://ejournal.unsrat.ac.id/index.php/jikmu/article/view/7443. 
Dhewy, A. (2019). Critical Discourse Analysis of Abortion Article on Law on Health and Government Regulation of Reproductive Health. Jurnal Perempuan, 22(2), 147-153. http://www.indonesianfeministjournal.org/index.php/IFJ/article/view/180.

Fadhila, F. (2017). Hubungan antara pengetahuan tentang pubertas dengan kecemasan menghadapi menarche: studi pada siswi kelas V Dan VI di SD Plus Al-Ghifari Kota Bandung. UIN Sunan Gunung Djati Bandung.

Fiorillo, A., Volpe, U., \& Bhugra, D. (2016). Psychiatry In Practice.

Hagedorn. R. (1990). Sociology (4th ed.). John Deyell Company.

Hati, K., Shaluhiyah, Z., \& Suryoputro, A. (2013). Stigma Masyarakat Terhadap ODHA Di Kota Kupang Provinsi NTT. Jurnal Promosi Kesehatan Indonesia, 12(1), 62-77.

Huda, S. (2015). KUA dan pernikahan dini: studi analisis eksistensi KUA Silo-Jember dalam perspektif pengendalian sosial tahun 2014. IAIN Jember.

ICRW. (2005). Development Initiative on Supporting Healthy Adolescents (DISHA) project: Analysis of quantitative baseline survey data conducted in 2004. ICRW.

Jamilah, J., \& Raudlatun, R. (2019). Fenomena pernikahan anak di Sumenep Madura. Jurnal Harkat: Media Komunikasi Gender, 15(1), 34-39. http://journal.uinjkt.ac.id/index.php/psga/article/view/13437

Miles, M., Huberman, A., \& Saldaña, J. (2014). Analisis Data Kualitatif (Thousand O). Sage Publication.

Mubasyaroh. (2016). Analisis Faktor Penyebab Pernikahan Dini dan Dampaknya Bagi Pelakunya. Jurnal Yudisia, 7(2). http://journal.iainkudus.ac.id/index.php/Yudisia/article/view/2161.

Nasrin, O. (2012). Factors affecting early marriage and early conception of women: A case of slum areas in Rajshahi City, Bangladesh. International Journal of Sociology and Anthropology, 4(2), 54-62. https://doi.org/10.5897/ijsa11.145.

Poloma, M. M. (2000). Sosiologi Kontemporer. CV. Rajawali.

Putra, N., \& Lestari, D. (2013). Penelitian Kualitatif PAUD (Pendidikan Anak Usia Dini). RajaGrafindo Persada.

Sa'diyah, E, H. (2013). Dimensi perilaku promosi kesehatan remaja berdasarkan perbedaan jenis kelamin. Psikoislamika, 10(1). http://repository.uin-malang.ac.id/804/.

Subana, \& Sudrajat, M. (2009). Dasar-dasar Penelitian Ilmiah. CV Pustaka Setia.

Sugiyono, H. (2016). Metode kualitatif dan kuantitatif. Alfabeta.

UNICEF. (2005). Early Marriage: A Harmful Traditional Practice: A Statistical Exploration. UNICEF.

Utami, W. (2018). Pengaruh Persepsi Stigma Sosial Dan Dukungan Sosial Terhadap Kesejahteraan Psikologis Pada Narapidana. Journal An-Nafs: Kajian Penelitian Psikologi, 3(2), 183-207. https: //eprints.umm.ac.id/58391/.

Varamitha, S., Akbar, S. N., \& Erlyani, N. (2016). Stigma Sosial pada Keluarga Miskin dari Pasien Gangguan Jiwa. Jurnal Ecopsy, 1(3). https://ppjp.ulm.ac.id/journal/index.php/ecopsy/article/view/498. 